\title{
RESPONSE OF NIGELLA SATIVA L. GROWTH AND OIL YIELD TO FOLIAR APPLICATION OF DRY YEAST, SALICYLIC ACID AND ASCORBIC ACID
}

\author{
E.Y. Abdul-Hafeez ${ }^{*}$ and T.M.A. Soliman ${ }^{* *}$ \\ * Department of Ornamental and Medicinal Plants, Faculty of Agriculture, Assiut University, Egypt \\ ** Department of Horticulture, Faculty of Agriculture, New Valley University, Egypt
}

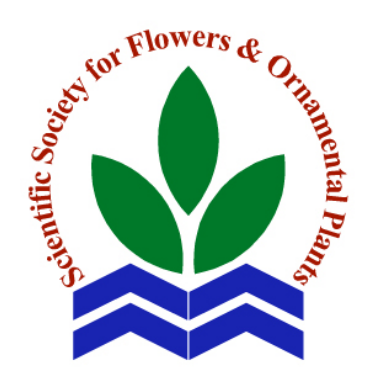

Scientific J. Flowers \& Ornamental Plants, 7(4):393-400(2020).

Received:

25/8/2020

Accepted:

$29 / 10 / 2020$

ABSTRACT: This study was carried out to evaluate the effects of dry yeast (0.4 and $0.8 \%$ ), salicylic acid (150 and $300 \mathrm{ppm})$ and ascorbic acid (150 and $300 \mathrm{ppm}$ ) as a spray application on black cumin plants to determine their effects on plant height, number of branches/plant, stem diameter, root length, capsule number/plant, capsules weight/plant, seed weights/plant, seed yield/fed, fixed oil percentage and oil yield/fed during both seasons. The highest concentration of each substance showed superiority in comparison with the lowest concentration of the same substance and the control. Salicylic acid at rate of $300 \mathrm{ppm}$ showed significant increase in plant height, seed weight, seed yield and fixed oil yield. Meanwhile, Ascorbic acid at rate of $300 \mathrm{ppm}$ presented significant increment in number of branches/plant, capsules number/plant, capsules weight and oil percentage. Dry yeast at rate $0.8 \%$ caused an increase in the root length which calculated at the first season as $17.15 \mathrm{~cm}$ and at the second season as $16.45 \mathrm{~cm}$.

Key words: Nigella sativa, black cumin, dry yeast, salicylic acid, ascorbic acid.

\section{INTRODUCTION}

Black cumin (Nigela sativa L.) is an annual herbaceous belongs to family Ranunculaceae. The plant is native to $\mathrm{S}$. Europe, N. Africa and SW Asia. The seeds contain two kinds of oil components; the first is dark-colored fragrant and volatile, the other more clearly (colorless) and majority consisting of castor oil. Medicinally, both the oils are regarded as aromatic, carminative, stomachic and digestive. The seeds are diuretic, digestive, carminative, emmenagogue, kill intestinal worms and relieve flatulence. Also used in cases of stone in bladder and kidneys, as well as in chronic fever due to phlegm, rheumatism, gout and sciatica, (Gupta, 2010). Fixed oil of Nigella seeds is rich in linoleic, oleic and palmitic acids. The dominating fatty acid is linoleic acid, which is an essential fatty acid and accounts for more than $50 \%$ of the total fatty acids (Atta, 2003). The crude extract from the black cumin seed in vitro was found to have spasmolytic and bronchodilator activities (Gilani et al., 2001).

Active dry yeast is a natural safety biofertilizers causes various promotive effects on plants. It is considered as a natural source of cytokinins which simulates cell division and enlargement as well as the synthesis of protein, nucleic acid and vitamin $\mathrm{B}$ (Amer, 2004). It also releases $\mathrm{CO}_{2}$ which reflected in improving net photosynthesis (Kurtzman and Fell, 2005). Salicylic acid (SA) is a compound that is chemically like aspirin. It functions as a phytohormone, an important factor in environmental stress tolerance in plants (Bosch et al., 2007).

Salicylic acid (SA) is an essential component of plant resistance to pathogens and also plays an important role in mediating 


\section{E.Y. Abdul-Hafeez and T.M.A. Soliman}

plant responses to some abiotic stresses (He et al., 2010). The application of SA may either be harmful or provide protection during abiotic stress, depending on the plant species, concentration and the mode of application (Horváth et al., 2007). The SA produces an ameliorative protective effect in plants in response to abiotic stress, such as metal toxicity, heat, chilling, osmotic and salt stress (Borsani et al., 2001; Janda et al., 1999.; Singh and Usha, 2003.; Wang and Li, 2006; Gunes et al., 2007; He and Zhu, 2008; Szepesi et al., 2008; Ivanova et al., 2008; Popova et al., 2009 and Gondor et al., 2016) and drought stress (Bechtold et al., 2010).

Ascorbic acid (Vitamin C) is synthesized in the higher plants and influences plant growth and development and plays an important role in the electron transport system (El-Kobisy et al., 2005). Blokhina et al. (2003) reported that ascorbic acid can be a regulator on cell division and differentiation and has an important role in a wide range of functions such as antioxidant defense, regulation of photosynthesis and growth. Ascorbic acid is a cofactor for many enzymes such as ones involved in the cell wall synthesis and hydroxylation of proline residues (Ishikawa et al., 2006).

The aim of this study was evaluation of the effects of dry yeast, salicylic acid and ascorbic acid on growth and fixed oil constituent of black cumin plants.

\section{MATERIALS AND METHODS}

The present study was conducted during the two successive winter seasons of $2016 / 2017\left(1^{\text {st }}\right.$ season $)$ and $2017 / 2018\left(2^{\text {nd }}\right.$ season) at the Farm of Ornamental Plants,
Faculty of Agriculture, New Valley University (latitude $25^{\circ} 41^{\prime} 41.1072 " \mathrm{~N}$, longitude $28^{\circ} 52^{\prime} 56.5320^{\prime \prime} \mathrm{E}$, and altitude $402 \mathrm{~m}$ ) to study the effect of dry yeast, salicylic acid and ascorbic acid foliar application at different concentrations on some vegetative growth parameters, seed yield and fixed oil production of black cumin (Nigella sativa L.) plants. Seeds of black cumin were obtained from the Medicinal and Aromatic Plants Section of Agric. Res. Center, El-Dokki, Cairo, Egypt. Soil analysis before the application is shown in Table (1). The maximum and minimum temperature as well as the relative humidity of the experimental location which were obtained from the Meteorological Station at the Experimental Farm, Faculty of Agriculture, New Valley University are presented in Table (2).

An experimental field was consisted of 21 plots in three replicates, each plot was 2 $\mathrm{m}^{2}$, and contained 3 rows with 30 plants, the distance between hills was $25 \mathrm{~cm}$, every hill contained 2 plants. Seeds were sown on $15^{\text {th }}$ of November during the two winter seasons.

Plants were allowed to grow for 60 days, after which time foliar application treatments were begun. Active dry yeast (Saccharomycess cerevisiae) in powder form purchased from the local market. Yeast activation done overnight by sucrose before spraying on the plants. Salicylic acid and ascorbic acid produced by El-Nasr Co. for Intermediate Chemicals, Egypt (NCIC). Calcium super phosphate $\left(\begin{array}{lll}15.5 \% & \mathrm{P}_{2} \mathrm{O}_{5}\end{array}\right)$; ammonium nitrate $(33.5 \% \mathrm{~N})$ and potassium fertilizer (potassium sulphate $48 \% \quad \mathrm{~K}_{2} \mathrm{O}$ )

Table 1. Physical and chemical properties of the experimental soil.

\begin{tabular}{|c|c|c|c|c|c|c|c|c|c|}
\hline \multicolumn{2}{|c|}{$\begin{array}{c}\text { Particle size } \\
\text { distribution }(\%)\end{array}$} & \multicolumn{2}{|c|}{ Chemical properties } & \multicolumn{4}{|c|}{$\begin{array}{l}\text { Water soluble ions meq/100 g } \\
\text { soil }\end{array}$} & \multicolumn{2}{|c|}{$\begin{array}{l}\text { Available nutrients } \\
\qquad\left(\mathrm{mg} \mathrm{kg}^{-1}\right)\end{array}$} \\
\hline Coarse sand & 4.71 & E.C dsm ${ }^{-1}(1: 5$ ex. $)$ & 1.09 & $\mathrm{Ca}^{+2}$ & 1.13 & $\mathrm{HCO}_{3}^{-}$ & 1.29 & $\mathbf{N}$ & 51.3 \\
\hline Fine sand & 72.65 & pH $(1: 2.5 \mathrm{w} / \mathrm{v})$ & 8.11 & $\mathbf{M g}^{+2}$ & 0.79 & $\mathrm{Cl}^{-}$ & 3.15 & $\mathbf{P}$ & 5.48 \\
\hline Silt & 14.55 & Organic matter $(\%)$ & 0.55 & $\mathbf{N a}^{+}$ & 3.37 & $\mathrm{SO}_{4}^{-2}$ & 1.14 & $\mathbf{K}$ & 141.3 \\
\hline Clay & 8.09 & $\mathrm{CaCO}_{3}(\%)$ & 5.42 & $\mathbf{K}^{+}$ & 0.29 & & & & \\
\hline Texture class & Sandy & SP \% & 40.3 & $\mathrm{CO}_{3}{ }^{-2}$ & 0.00 & & & & \\
\hline
\end{tabular}


Table 2. Monthly average of metrological data of the experimental farm during 2016/2017 and 2017/2018 seasons.

\begin{tabular}{|c|c|c|c|c|c|c|c|}
\hline \multirow{3}{*}{ Month } & \multirow{3}{*}{ Day } & \multicolumn{3}{|c|}{$2016 / 2017$} & \multicolumn{3}{|c|}{$2017 / 2018$} \\
\hline & & \multicolumn{2}{|c|}{ Temperature ${ }^{\circ} \mathbf{C}$} & \multirow{2}{*}{ Humidity \% } & \multicolumn{2}{|c|}{ Temperature ${ }^{\circ} \mathrm{C}$} & \multirow{2}{*}{ Humidity \% } \\
\hline & & Max. & Min. & & Max. & Min. & \\
\hline \multirow{4}{*}{ November } & $1-10$ & 30.9 & 17.3 & 39.0 & 27.7 & 15.6 & 44.0 \\
\hline & $11-20$ & 31.2 & 18.1 & 41.0 & 30.4 & 12.4 & 41.0 \\
\hline & 21-30 & 27.9 & 12.6 & 41.0 & 24.4 & 10.8 & 47.0 \\
\hline & Average & 30.0 & 16.0 & 40.3 & 27.5 & 12.9 & 44.0 \\
\hline \multirow{4}{*}{ December } & 1-10 & 24.0 & 11.5 & 48.0 & 23.2 & 11.1 & 45.0 \\
\hline & $11-20$ & 21.7 & 8.0 & 51.0 & 27.4 & 13.5 & 44.0 \\
\hline & 21-31 & 20.4 & 6.7 & 54.0 & 23.9 & 11.3 & 50.0 \\
\hline & Average & 22.0 & 8.7 & 51.0 & 24.8 & 11.9 & 46.3 \\
\hline \multirow{4}{*}{ January } & $1-10$ & 19.7 & 4.5 & 52.0 & 22.7 & 5.9 & 50.0 \\
\hline & $11-20$ & 23.3 & 7.9 & 48.0 & 22.9 & 7.5 & 46.0 \\
\hline & 21-31 & 22.8 & 8.3 & 44.0 & 21.2 & 5.9 & 52.0 \\
\hline & Average & 21.9 & 6.9 & 48.0 & 22.2 & 6.4 & 49.3 \\
\hline \multirow{4}{*}{ February } & 1-10 & 23.0 & 7.4 & 42.0 & 31.4 & 10.8 & 37.0 \\
\hline & $11-20$ & 24.0 & 6.5 & 45.0 & 24.7 & 11.5 & 45.0 \\
\hline & 21-28 & 26.5 & 8.2 & 46.0 & 30.3 & 13.3 & 38.0 \\
\hline & Average & 24.5 & 7.3 & 44.3 & 28.8 & 11.8 & 40.0 \\
\hline \multirow{4}{*}{ March } & 1-10 & 25.9 & 9.3 & 44.0 & 34.9 & 13.8 & 34.0 \\
\hline & $11-20$ & 26.6 & 10.5 & 42.0 & 33.2 & 14.2 & 30.0 \\
\hline & 21-31 & 29.8 & 13.7 & 34.0 & 34.0 & 16.3 & 25.0 \\
\hline & Average & 27.4 & 11.1 & 40.0 & 34.0 & 14.7 & 29.6 \\
\hline \multirow{4}{*}{ April } & $1-10$ & 32.0 & 16.6 & 32.0 & 32.0 & 15.6 & 30.0 \\
\hline & $11-20$ & 34.3 & 17.8 & 30.0 & 40.0 & 20.3 & 21.0 \\
\hline & 21-30 & 36.2 & 19.7 & 25.0 & 34.9 & 17.2 & 27.0 \\
\hline & Average & 34.1 & 18.0 & 29.0 & 35.6 & 17.7 & 26.0 \\
\hline
\end{tabular}

were applied two times, after 45 and 75 day from sowing, with the recommended doses for all treatments.

The experimental design was factorial experiment in randomized complete block design seven treatments including with three replicates as follows:

- Control (tap water).

- Active dry yeast $0.4 \%$.

- Active dry yeast $0.8 \%$.

- Salicylic acid at rate $150 \mathrm{ppm}$.

- Salicylic acid at rate $300 \mathrm{ppm}$.

- Ascorbic acid at rate $150 \mathrm{ppm}$.

- Ascorbic acid at rate 300 ppm.
Black cumin plants were collected at the harvest date after six months from sowing on $10^{\text {th }}$ May during both seasons. Ten plants were randomly collected from each treatment and the following characters were recorded: plant height ( $\mathrm{cm} /$ plant), number of branches/plant, stem diameter $(\mathrm{cm})$, root length $(\mathrm{cm})$, capsules number/plant, capsules weight (g/plant), seed weights (g/plant), seed yield $(\mathrm{kg} / \mathrm{fed})$, fixed oil $\%$ and fixed oil yield $(1 /$ fed). Fixed oil productivity $(\%)$ and yield ( $1 /$ fed) was estimated as described by Munshi (1987). Powder of each sample estimated by Soxhlet apparatus using hexane solvent (40 $\left.60{ }^{\circ} \mathrm{C}\right)$.

Collected data were subjected to the statistical analysis according to the technique of variance (ANOVA) of factorial 


\section{E.Y. Abdul-Hafeez and T.M.A. Soliman}

experiment in RCB design. The treatments means were compared using the least significant differences (L.S.D.) at 5\% procedure as mentioned by Gomez and Gomez, (1984). Statistical analysis was performed using Statistix 8.1 program.

\section{RESULTS AND DISCUSSION}

Data in Table (3) showed that spraying black cumin plants with dry yeast $(0.4$ and $0.8 \%$ ), salicylic acid (150 and $300 \mathrm{ppm}$ ) and ascorbic acid (150 and $300 \mathrm{ppm}$ ) reflected on significant effects on plant height, number of branches/plant, stem diameter, root length and capsule number/plant in both seasons. Data in Table (4) showed the significant effects on capsules weight/plant, seed weights/plant, seed yield/fed, fixed oil percentage and oil yield/fed. The highest concentration of each substance was superior in comparison with those of the same substance at the lower concentrations and the control. Salicylic acid at rate of $300 \mathrm{ppm}$ significantly increased plant height $(60.25$ and $58.25 \mathrm{~cm} /$ plant for the first and second seasons respectively), seed weight (13.75 and $15 \mathrm{~g} /$ plant for both seasons respectively), seed yield (550 and $600 \mathrm{~kg} / \mathrm{fed}$ for both seasons respectively) and fixed oil yield (138.90 and 145.93 1/fed for first and second seasons, respectively). Meanwhile, Ascorbic acid at rate of $300 \mathrm{ppm}$ showed significant increase in number of branches/plant (9.78 at the first season and 8.83 at the second

Table 3. Effect of dry yeast, salicylic acid and ascorbic acid treatments on vegetative growth parameters of black cumin plants during both seasons.

\begin{tabular}{|c|c|c|c|c|c|c|c|c|c|c|}
\hline \multirow{2}{*}{ Treatments } & \multicolumn{2}{|c|}{$\begin{array}{c}\text { Plant height } \\
\text { (cm/plant) }\end{array}$} & \multicolumn{2}{|c|}{$\begin{array}{c}\text { Number of } \\
\text { branches/plant }\end{array}$} & \multicolumn{2}{|c|}{$\begin{array}{l}\text { Stem diameter } \\
(\mathrm{cm})\end{array}$} & \multicolumn{2}{|c|}{$\begin{array}{l}\text { Root length } \\
(\mathrm{cm})\end{array}$} & \multicolumn{2}{|c|}{$\begin{array}{l}\text { Capsules } \\
\text { No./plant }\end{array}$} \\
\hline & $\begin{array}{c}1^{\text {st }} \\
\text { season } \\
\end{array}$ & $\begin{array}{c}2^{\text {nd }} \\
\text { season } \\
\end{array}$ & $\begin{array}{c}1^{\text {st }} \\
\text { season } \\
\end{array}$ & $\begin{array}{c}2^{\text {nd }} \\
\text { season } \\
\end{array}$ & $\begin{array}{c}1^{\text {st }} \\
\text { season } \\
\end{array}$ & $\begin{array}{c}2^{\text {nd }} \\
\text { season } \\
\end{array}$ & $\begin{array}{c}1^{\text {st }} \\
\text { season } \\
\end{array}$ & $\begin{array}{c}2^{\text {nd }} \\
\text { season } \\
\end{array}$ & $\begin{array}{c}1^{\text {st }} \\
\text { season } \\
\end{array}$ & $\begin{array}{c}2^{\text {nd }} \\
\text { season } \\
\end{array}$ \\
\hline Control (water) & 48.53 & 44.43 & 7.53 & 6.43 & 5.38 & 5.68 & 12.70 & 12.23 & 34.25 & 29.08 \\
\hline Yeast $0.4 \%$ & 53.75 & 55.58 & 8.08 & 7.54 & 6.76 & 6.55 & 13.93 & 13.00 & 48.50 & 46.58 \\
\hline Yeast $0.8 \%$ & 55.00 & 57.75 & 8.75 & 7.63 & 6.99 & 6.67 & 17.15 & 16.45 & 52.63 & 46.99 \\
\hline Salicylic 150 ppm & 56.00 & 55.44 & 7.73 & 6.17 & 6.03 & 6.48 & 14.25 & 14.21 & 40.55 & 44.25 \\
\hline Salicylic 300 ppm & 60.25 & 58.25 & 8.53 & 6.67 & 6.98 & 6.54 & 15.73 & 15.00 & 49.00 & 46.92 \\
\hline Ascorbic 150 ppm & 52.02 & 48.69 & 9.70 & 7.93 & 6.51 & 6.42 & 14.41 & 12.74 & 54.50 & 51.25 \\
\hline Ascorbic 300 ppm & 55.68 & 50.13 & 9.78 & 8.83 & 6.81 & 6.61 & 14.66 & 13.42 & 59.00 & 53.75 \\
\hline L.S.D. at 5\% & 4.11 & 2.78 & 1.00 & 0.68 & N.S. & N.S. & 0.86 & 1.38 & 2.99 & 3.53 \\
\hline
\end{tabular}

Table 4. Effect of dry yeast, salicylic acid and ascorbic acid treatments on yield components and fixed oil production of black cumin plants during both seasons.

\begin{tabular}{|c|c|c|c|c|c|c|c|c|c|c|}
\hline \multirow{2}{*}{ Treatments } & \multicolumn{2}{|c|}{$\begin{array}{c}\text { Capsules weight } \\
\text { (g/plant) }\end{array}$} & \multicolumn{2}{|c|}{$\begin{array}{c}\text { Seed weights } \\
\text { (g/plant) }\end{array}$} & \multicolumn{2}{|c|}{$\begin{array}{l}\text { Seed yield } \\
\text { (kg/fed) }\end{array}$} & \multicolumn{2}{|c|}{ Oil \% } & \multicolumn{2}{|c|}{ Oil yield $(\mathrm{l} / \mathrm{fed})$} \\
\hline & $\begin{array}{c}1^{\text {st }} \\
\text { season }\end{array}$ & $\begin{array}{c}2^{\text {nd }} \\
\text { season }\end{array}$ & $\begin{array}{c}1^{\text {st }} \\
\text { season }\end{array}$ & $\begin{array}{c}2^{\text {nd }} \\
\text { season }\end{array}$ & $\begin{array}{c}1^{\text {st }} \\
\text { season }\end{array}$ & $\begin{array}{c}2^{\text {nd }} \\
\text { season }\end{array}$ & $\begin{array}{c}1^{\text {st }} \\
\text { season } \\
\end{array}$ & $\begin{array}{c}2^{\text {nd }} \\
\text { season }\end{array}$ & $\begin{array}{c}1^{\text {st }} \\
\text { season } \\
\end{array}$ & $\begin{array}{c}2^{\text {nd }} \\
\text { season }\end{array}$ \\
\hline Control (water) & 9.83 & 8.77 & 8.13 & 8.98 & 325.00 & 359.00 & 23.15 & 23.13 & 75.27 & 82.90 \\
\hline Yeast $0.4 \%$ & 16.25 & 16.50 & 12.40 & 13.58 & 495.80 & 543.00 & 24.23 & 23.73 & 120.06 & 129.02 \\
\hline Yeast $0.8 \%$ & 17.39 & 17.52 & 13.16 & 14.75 & 526.20 & 590.00 & 24.83 & 24.85 & 131.63 & 146.46 \\
\hline Salicylic 150 ppm & 13.00 & 15.41 & 11.88 & 13.38 & 475.30 & 535.00 & 24.75 & 23.63 & 117.48 & 126.33 \\
\hline Salicylic 300 ppm & 13.70 & 15.83 & 13.75 & 15.00 & 550.00 & 600.00 & 25.25 & 24.30 & 138.90 & 145.93 \\
\hline Ascorbic 150 ppm & 17.25 & 17.69 & 10.63 & 12.13 & 425.10 & 485.00 & 25.53 & 26.07 & 108.82 & 126.47 \\
\hline Ascorbic 300 ppm & 19.13 & 18.00 & 11.24 & 12.38 & 449.40 & 495.00 & 26.37 & 26.70 & 118.74 & 132.20 \\
\hline L.S.D. at 5\% & 1.69 & 3.03 & 1.32 & 1.42 & 52.72 & 56.86 & 1.22 & 1.05 & 14.93 & 14.43 \\
\hline
\end{tabular}


season), capsules number/plant (59.00 and 53.75 for the both seasons, respectively), capsules weight (19.13 and $18.00 \mathrm{~g} /$ plant for the first and second seasons, respectively) and oil percentage (26.37 and $26.70 \%$ for both seasons, respectively). Dry yeast at rate of $0.8 \%$ caused an increase in the root length which calculated at the first season as 17.15 $\mathrm{cm}$ and at the second season as $16.45 \mathrm{~cm}$.

Salicylic acid is effective in the buds blossoming, the permeability of the membrane, mitochondrial respiration, stomata closure, material handling, photosynthesis, growth and the absorption of ions (Senaranta et al., 2000). Several studies have been conducted that exogenous salicylic acid application enhances plant growth and development. Fariduddin et al. (2003) showed that mustard plants sprayed with low concentrations of salicylic acid produced larger amounts of dry matter and had higher photosynthetic rate in comparison with control plants. Salicylic acid application to corn and soybean promoted dry weight of plants (Khan et al., 2003). In another study, Hussein et al. (2007) revealed that growth traits of wheat plants were improved as a result of salicylic acid spraying on the plants.

An experiment showed that plants were sprayed with ascorbic acid at 2, 4, 6 and 8 $\mathrm{ml} / \mathrm{l}$ resulted increasing in weight of seed yield/fed, weight of pod yield, weight of 1000 seed and number of branches per plant (Khafaga et al., 2014). A report illustrated that ascorbic acid and $\alpha$-tocopherol affected the growth and some chemical compounds of Hibiscus rosa sineses (El-Quesni et al., 2009). Ascorbic acid is an antioxidant and, in association with other components of the antioxidant system, protects plants from oxidative damage resulting from aerobic metabolism, photosynthesis and a range of pollutants like ozone, heavy metal and saline stress. In addition, it is not only an antioxidant; it also appears as a co-factor for several metabolic enzymes involved in the fundamental developmental process of plants and a well-known cellular reductant with an intimate and comprehensive role in the response to environmental stress. Also, some studies suggest that the endogenous AA has been implicated in the promotion of plant growth and development by involving in a complex array of phytohormone-mediated signaling network that ties together different environment stress (Mazid et al., 2011).

Stimulating vegetative growth by using dry yeast may be due to its influence on the nutritional signal transduction producing growth regulators and suppressing pathogen (El-Ghadban et al., 2003). It is also a natural source of cytokinins that stimulates cell proliferation and differentiation, controlling shoot and root morphogenesis and chloroplast maturation (Amer, 2004).

\section{REFERENCES}

Amer, S.S.A. (2004). Growth, green pods yield and seeds yield of common bean (Phaseolus vulgaris L.) as affected by active dry yeast, salicylic acid and their interaction. J. Agric Sci. Mansoura Univ., 29 (3):1407-1422.

Atta, M.B. (2003). Some characteristics of nigella (Nigella sativa L.) seed cultivated in Egypt and its lipid profile. Food Chem., 83 (1):63-68. doi:10.1016/S03088146(03)00038-4

Bechtold, U.; Lawson, T.; Mejia-Carranza, J.; Meyer, R.C.; Brown, I.R.; Altmann, T.; Ton, J. and Mullineaux, P.M. (2010). Constitutive salicylic acid defenses do not compromise seed yield, drought tolerance and water productivity in the Arabidopsis accession C24. Plant Cell Environ., 33 (11):1959-1973. doi: 10.1111/j.1365-3040.2010.02198.x

Blokhina, O.; Virolainen, E. and Fagerstedt, K.V. (2003). Antioxidant, oxidative damage and oxygen deprivations stress: A Review. Ann. Bot., 91(2):179-194. doi.org/10.1093/aob/mcf118.

Borsani, O.; Valpuesta, V. and Botella, M.A. (2001). Evidence for a role of salicylic acid in the oxidative damage generated by $\mathrm{NaCl}$ and osmotic stress in Arabidopsis seedling. J. Plant Physiol., 


\section{E.Y. Abdul-Hafeez and T.M.A. Soliman}

126(3):1024-1030. doi.org/10.1104/pp. 126.3.1024

Bosch, S.M.; Penuelas, J. and Liusia, J. (2007). A deficiency in salicylic acid alters isoprenoid accumulation in waterstressed NahG transgenic Arabidopsis plants. Plant Sci., 172(4):756-762. doi.org/10.1016/j.plantsci.2006.12.005.

El-Ghadban, E.A.E.; Kutb, S.A. and Eid, M.I. (2003). Effect of foliar spraying with active dry yeast and complete fertilizer (sengral) on growth, yield and fixed oil of (Ricinus communis). Egypt. Pharm. J., 1(1):55-66.

El-Kobisy, D.S.; Kady, K.A.; Medani, R.A. and Agamy, R.A. (2005). Response of pea plant (Pisum sativum L.) to treatment with ascorbic acid. Egypt. J. Appl. Sci., 20:36-50.

El-Quesni, F.E.M.; Abd El-Aziz, N.G. and Kandil, M.M. (2009). Some studies on the effect of ascorbic acid and $\alpha$ tocopherol on the growth and some chemical composition of Hibiscus rosa sineses L. at Nubaria. Ozean J. App. Sci., 2(2):159-167.

Fariduddin, Q.; Hayat, S. and Ahmad, A. (2003). Salicylic acid influences net photosynthetic rate, carboxylation efficiency, nitrate reductase activity and seed yield in Brassica juncea. Photosynthetica, 41:281-284. doi.org/10.1023/B:PHOT.0000011962.05 991.6c.

Gilani, A.H.; Aziz, N.; Khurram, I.M.; Chaudhary, K.S. and Libel, A. (2001). Bronchodilator, spasmolytic and calcium antagonistic activities of Nigella sativa seeds (Kalonji): a traditional herbal product with multiple medicinal uses. J. Pak. Med. Assoc., 51(3):115-120.

Gomez, K.H. and Gomez, A.A. (1984). Statistical Procedures for Agriculture Research. John Willy and Sons, Inc., New York, USA, $680 \mathrm{p}$.

Gondor, O.K.; Pál, M.; Darkó, É.; Janda, T. and Szalai, G. (2016). Salicylic acid and sodium salicylate alleviate cadmium toxicity to different extents in maize (Zea mays L.). PLOS ONE, 11(8):1-18. doi.org/10.1371/journal.pone.0160157

Gunes, A.; Inal, A.; Alpaslan, M.; Eraslan, F.; Bagci, E.G. and Cicek, N. (2007). Salicylic acid induced changes on some physiological parameters symptomatic for oxidative stress and mineral nutrition in maize (Zea mays L.) grown under salinity. J. Plant Physiol., 164(4):728736. doi.org/10.1016/j.jplph.2005.12.009

Gupta, R.K. (2010). Medicinal and Aromatic Plants, $1^{\text {st }}$ ed. CBS Publishers and Distributors, New Delhi, India, 622 p.

He, J.; Ren, Y.; Pan, X.; Yan, Y.; Zhu, C. and Jiang, D. (2010). Salicylic acid alleviates the toxicity effect of cadmium on germination, seedling growth, and amylase activity of rice. J. Plant Nutr.

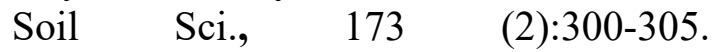
doi.org/10.1002/jpln.200800302

He, Y. and Zhu, Z.J. (2008). Exogenous salicylic acid alleviates $\mathrm{NaCl}$ toxicity and increases antioxidative enzyme activity in Lycopersicon esculentum. Biol. Plant, 52:792-795. doi.org/10.1007/s10535008-0155-8

Horváth, E.; Szalai, G. and Janda, T. (2007). Induction of abiotic stress tolerance by salicylic acid signaling. J. Plant Growth Regul., 26: 290-300. doi.org/10.1007/s00344-007-9017-4

Hussein, M.M.; Balbaa, L.K. and Gaballah, M.S. (2007). Salicylic acid and salinity effects on growth of maize plants. Res. J. Agric. Biol. Sci., 3(4):321-328.

Ishikawa, T.; Dowdle, J. and Smirnoff, N. (2006). Progress in manipulating ascorbic acid biosynthesis and accumulation in plants. Physiologia Plantarum, 126:343355. doi.org/10.1111/j.13993054.2006.00640.x

Ivanova, A.; Krantev, A.; Stoynova, Z.H. and Popova, L. (2008). Cd-induced changes in lipids of maize plants. Gen. Appl. Plant Physiol., 34:149-158. 
Janda, T.; Szalai, G.; Tari, I. and Paldi, E. (1999). Hydroponic treatment with salicylic acid decreases the effects of chilling injury in maize (Zea mays L) plants. Planta, 208:175-180. doi.org/10.1007/s004250050547

Khafaga, E.E.; Hasanin, E.E. and El-Shal, R.M. (2014). Effect of foliar application with ascorbic, humic acids and compost tea on nutrients content and faba bean productivity under sandy soil conditions. Journal of Soil Sciences and Agriculture Engineering, Mansura University, 5:767778.

Khan, W., Prithviraj, B. and Smith, D.L. (2003). Photosynthetic responses of corn and soybean to foliar application of salicylates. J. Plant Physiol., 160(5):485492. doi.org/10.1078/0176-1617-00865.

Kurtzman, C.P. and Fell, J.W. (2005). Yeast systematics and phylogeny: implications of molecular identification methods for studies in ecology. In: Péter, G. and Rosa C. (eds.), Biodiversity and Ecophysiology of Yeasts, Springer, Berlin, pp. 11-30.

Mazid, M.; Khan, T.A.; Khan, Z.H.; Quddusi, S. and Mohammad, F. (2011). Occurrence, biosynthesis and potentialities of ascorbic acid in plants. International Journal of Plant, Animal and Environmental Sciences, 1:167-184.
Munshi, S.K. (1987). Manual in Modern Analytical Techniques in Agricultural Biochemistry. Punjab Agric. Univ., Ludhiana, India, $226 \mathrm{p}$.

Popova, L.P.; Maslenkova, L.T.; Yordanova, R.Y.; Ivanova, A.P.; Krantev, A.P.; Szalai, G. and Janda, T. (2009). Exogenous treatment with salicylic acid attenuates cadmium toxicity in pea seedlings. Plant Physiol. Biochem., 47: 224-231. doi.org/10.1016/j.plaphy.2008.11.007

Senaratna, T.; Touchell, D.; Bunn, E. and Dixon, K. (2000). Acetylsalicylic acid (Aspirin) and salicylic acid induce multiple stress tolerance in bean and tomato. Plant Growth Regul., 30(2):15761. doi.org/10.1023/A:1006386800974

Singh, B. and Usha, K. (2003). Salicylic acid induced physiological biochemical changes in wheat seedlings under water stress. Plant Growth Regul., 39:137-141.

Szepesi, Á.; Poor, P.; Gémes, K.; Horváth, E. and Tari, I. (2008). Influence of exogenous salicylic acid on antioxidant enzyme activities in the roots of salt stressed tomato plants. Acta Biol. Szeged., 52:199-200.

Wang, L.J. and Li, S.H. (2006). Salicylic acid-induced heat or cold tolerance in relation to $\mathrm{Ca}^{2+}$ homeostasis and antioxidant systems in young grape plants. Plant Sci., 170:685-694.

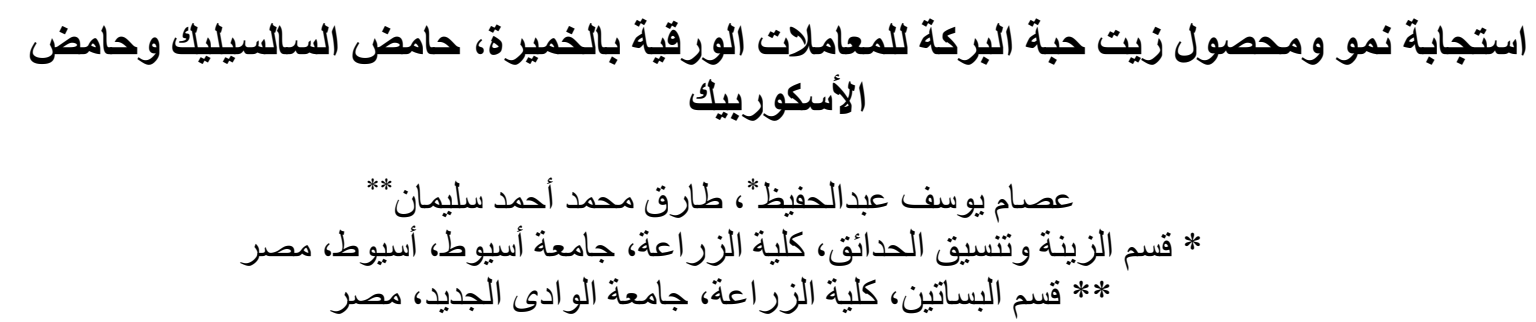

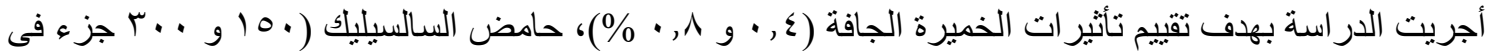

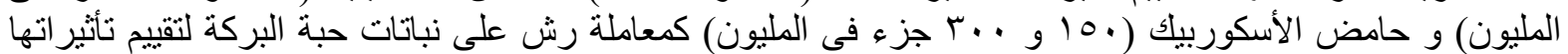

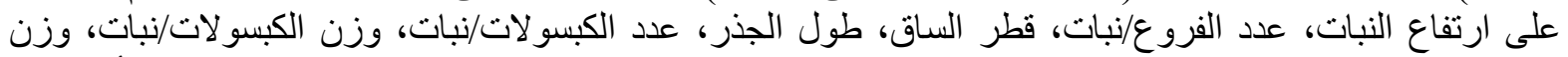

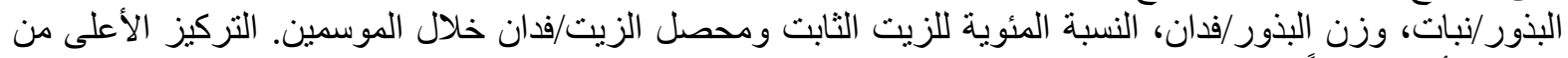

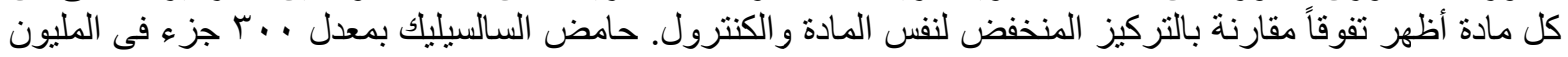




\section{E.Y. Abdul-Hafeez and T.M.A. Soliman}

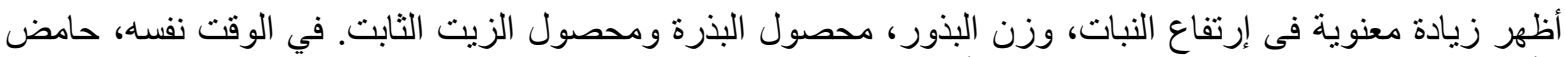

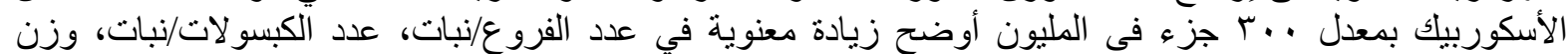

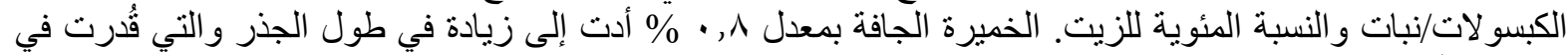

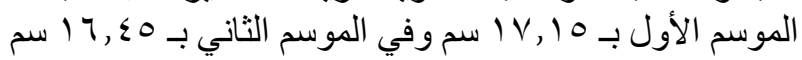

